\title{
Anthrovision
}

Vaneasa Online Journal

$4.2 \mid 2016$

Imagination/Ineffability

\section{Picturing Intimacy}

Mediation and Self-representation in Boston's Religious Festivals

\section{Federico De Musso and Cristina Grasseni}

\section{(2) OpenEdition}

\section{Journals}

Electronic version

URL: https://journals.openedition.org/anthrovision/2359

DOI: 10.4000/anthrovision.2359

ISSN: 2198-6754

Publisher

VANEASA - Visual Anthropology Network of European Association of Social Anthropologists

Electronic reference

Federico De Musso and Cristina Grasseni, "Picturing Intimacy", Anthrovision [Online], 4.2 | 2016, Online since 31 December 2016, connection on 16 August 2022. URL: http://journals.openedition.org/ anthrovision/2359; DOI: https://doi.org/10.4000/anthrovision.2359

This text was automatically generated on 16 August 2022

All rights reserved 


\title{
Picturing Intimacy
}

Mediation and Self-representation in Boston's Religious Festivals

\author{
Federico De Musso and Cristina Grasseni
}

\section{Introduction}

1 Traditionally, several "societies of the saints" exist in Boston's Little Italy, as in many other American cities with an Italian American immigrant community (Ferraiuolo 2009). Taking collective remembrance as a point of departure, we engage with it moving beyond the canon of observational cinema, addressing the limits and potential of montage, and incorporating the multi-vocality that social networks afford back into the linearity of a largely narrated film. In this article, we discuss how editing found footage into the film Christmas in August. Boston's St. Anthony's Feast (2013, http:// christmasinaugust.altervista.org/) was a way to explore the assemblages of diasporic identity and cultural intimacy for Boston's Italian Americans. Based on fieldwork by Cristina Grasseni in Boston's North End (Grasseni 2014) and edited by Federico De Musso, the film is about the social practice and the cultural memory of religious processions in the North End. In "The Atlas and the Film", Grasseni proposes the Atlas and Montage as two modes of representation, both de-constructing the observational canon of ethnographic filmmaking. Atlas and Montage work collaboratively as two complementary strategies that allow for in depth-analysis, cross-referencing, and annotation on the one hand (the Atlas), as well as the contamination of the different voices, viewpoints and temporalities that can be derived from the analytical treatment of disparate materials, on the other hand (Montage). This joint article positions itself in an ideal continuity with the arguments proposed there. While Grasseni (2014) focusses on her ethnographic fieldwork around the Boston's Feast and on her exploration of a digital annotation software in order to dissect and arrange the wealth of multi-media sources that pertain to a cultural analysis of St. Anthony's Feast, here we focus specifically on the significance of social networks' mediation, and of montage to capture and represent the virtual narratives of St. Anthony's Feast Facebook Group Page, rendering them in cinematic way. 
2 Video-recording Saint Anthony's Feast in Boston, reveals one of the most numerous group of participants, namely those who were busy taking pictures (see figure 1).

Photographing the Saint

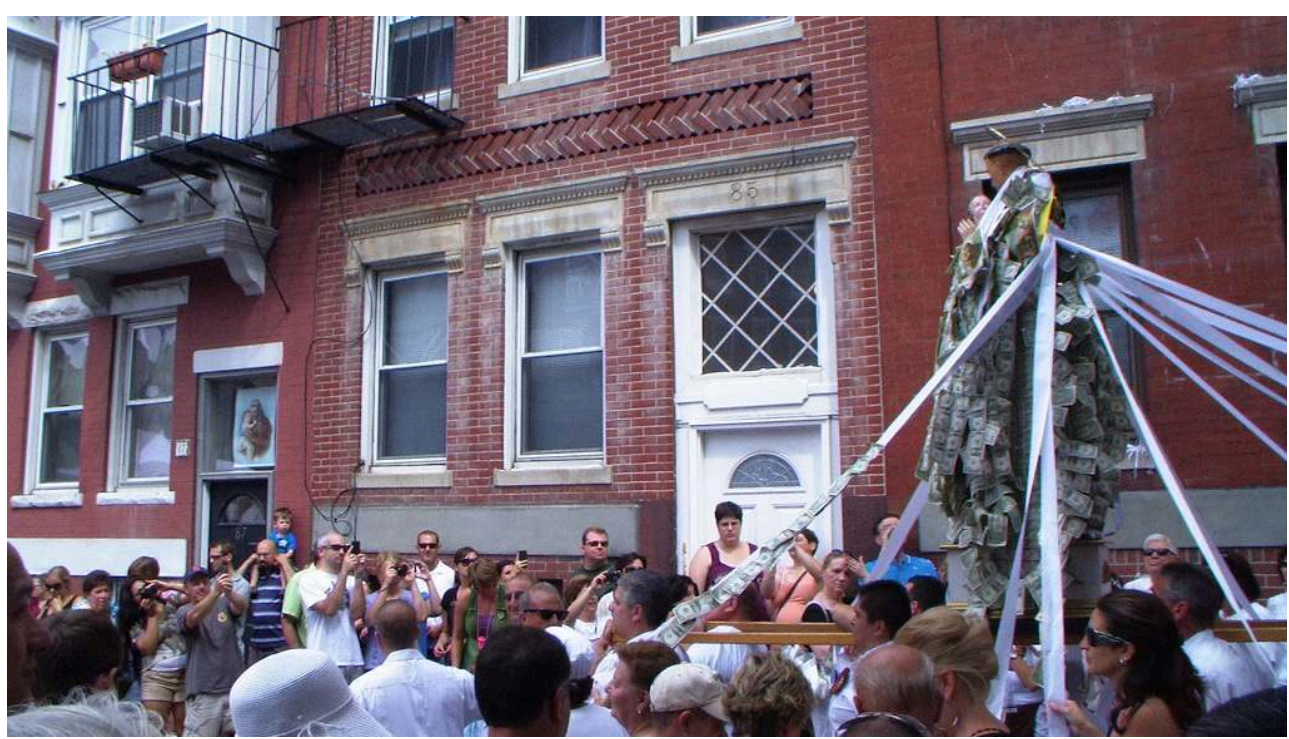

Figure 1. Boston, North End, August 2011.

Photo by Cristina Grasseni

3 The fact that people were taking pictures while participating in the feast might look like a trivial aspect of the event, especially if compared with the colourful grandiosity of the parade. However, it raises a question that is pertinent to this special issue: where do these images go? What sociocultural function do they exercise? And how can they be used to analyse and narrate the sociability that they embody?

4 First, we argue that in order to understand the stratified landscape of affection that envelops the North End, one has to consider the layers of sociability that compose the online community of the Feast's followers. Specifically, we consider videos of affinity (Lange 2009) and online groups as repository of community affiliation. Then we explain how we integrated those layers, represented by video material gathered on the social network pages of the Feast, through montage. We consider montage as the most suited editing technique to reproduce the intimacy and irony expressed by the protagonists. If Grimshaw and Ravetz (2009: 539) claim that observational cinema favors "seeing over assertion, wholeness over parts, matter over symbolic meaning, specificity over abstraction", the self-conscious exercise in this film was to play parts against each other, to voice symbolic dissonance, thus allowing disparate sources to speak for themselves while also making space for our own authorship.

5 Finally, we discuss the performance of Italian-ness itself, by looking at acts of commemoration and remembering. Throughout the paper we relate to the Internet as both an archive source and a field of performance.

\section{Digital Boston}

6 The circulation of social imaginaries about heritage and ethnicity is a typical configuration of contemporary urban ecologies of belonging. The public performance 
of religious devotion has been studied as an ethnic and territorial marker for the Italian-American communities of the East Coast (Posen \& Sciorra 1999, Sciorra 1985). In fact, the collective performance of musical processions in the streets of the North End epitomizes their "ephemeral identity" (Ferraiuolo 2009). According to anthropologist Augusto Ferraiuolo, in other words, the Italian identity associated with these religious festivals exists only insofar as it is collectively performed. The community performing the feast is no longer physically located for the most part in the North End, and the religious and social performativity plays up to a conspicuous absence of Italian residents in the contemporary North End - if one does not count the omnipresent restaurants, cafés, gourmet shops, souvenir kiosks etc. of a largely "touristified" location.

7 Studying festive practices in Boston as a form of 'Ecology of Belonging' is aimed to produce a complex understanding of place and belonging, applying the skilled visions approach to collective strategies of self-representation. Categorising self and other through reference to place-identity is common, but the sense of being 'in' or 'of' a place can acquire an inward-looking tinge (sometimes even a xenophobic tone) as a result of a social training of perception that recognizes the 'other' at first sight, classifying them according to a value-laden aesthetics of emplacement (Herzfeld 2012, Grasseni 2007).

The project Skilled Visions. Critical Ecologies of Belonging, which resulted in the film Christmas in August ${ }^{1}$, responded to the theoretical need of finding a visual anthropological method for interrogating identity as a relational process rather than as a substantive mode, wishing to make a film about how people look at themselves and peers. Considering that visual competence is invisible in itself, montage is the best tool to make the viewer think about looking. While it is impossible to acquire 'skilled vision' without undergoing the specific training that each and every one of us receives as part of our life-history, it is however possible to analyze cultural and collective modes of looking and to evoke them in film, by focusing on the social schoolings of the eye, and on the visual stereotypes about one's own and other people's outlook and social performances.

The capacity to read complex cultural cues around oneself depends on timescapes as well as multiple sense-scapes, and both are historically embedded - in the case of Boston's North End, in a heavily layered urban landscape. Such "layers" should be thought of in an archeological sense, as the resulting collective signification of places and practices through living together, but also, more pertinently in the contemporary era, by using and sharing picturing devices of one's places and practices.

The massive presence of media recording and publishing devices in everyday life is by now incontrovertible and has generated much cultural analysis as well as criticism (see for example Turkle 2012). The affordable price of consumer and prosumer digital cameras, the growing access to the internet and the incorporation of cameras in cell phones and smartphones allowed in the past decade a proliferation of images and videos that enhanced home-made production and at the same time superseded the more intimate consumption of photo albums, VHS tapes, super8 and slide projections within restricted circles of physically present friends.

11 Internet blogging and platforms such as Facebook, Flickr and YouTube, as well as subsequent applications for smartphone image-sharing (such as Instagram, Flickr, Snapchat, WhatsApp,...) has shaped a new social way of conceiving of personal memories and presence. As Daniel Miller and Don Slater (2000) state about Trinidad and Tobago, the Internet is not another place, dis-embedded from the social reality, but 
rather a part in this continuum of relations. To make sense of these relatively new aspects of community making, we incorporated found footage in our documentary as a way of rendering visible the social construction of a common digital memory.

Within this social and cultural framework, filming, producing selfies, or sharing clips amount to as many acts of memory that deal not so much with the epistemic ambition of representing facts or events, but rather produce relations through the practical means of recalling: asserting that such relations and communities indeed exist. Patricia Lange defines as videos of affinity those social media that aim to generate and maintain connections with other people on the web. They can "include feelings of membership in a social network, or feelings of attraction to people, things or ideas" (Lange 2009: 71). What brings together a community around specific topics is social interest in certain practices - in our case, what attracts the members of St. Anthony's Feast Facebook Group (https://www.facebook.com/StAnthonysFeast) could be one's Italian-American origins, or a personal link to Boston's North End, or devotion to St. Anthony, or a combination of such and other factors. Membership of an on-line group grants access to a discussion space in which everybody is entitled to participate and volunteer appreciation, comments, and sometimes debate. By uploading and liking, one experiences new ways of belonging and relating to others which, Lange argues, "have a present focus and communicative orientation" in contrast to the reminiscent prerogative of the home-mode media, characterized by spatial proximity (Lange 2009: 74). The affiliation on-line works in a synchronic manner, building a sense of community between the intended viewers and the video-makers, rather than building a relation to the video itself.

\section{Editing Intimacy}

13 As Rane Willerslev and Christian Suhr (2013) have recently argued, "montage provides a technique for evoking the invisible through the orchestration of different perspectives encroaching upon one another" (2013:298). The film Christmas in August explores montage as a device that exposes paradox rather than illustrating it, unraveling intimate memories and performative enactments by linking narration (verbal recollection) with visual and sonic records of the Feast (digital souvenirs). Firstly, Christmas in August attempts to recreate the friendly atmosphere of intimate recollection that characterises the narration of the Feast. For the interviewees, intimacy is signalled by their vivid recalling of childhood memories, kinship ties, and family devotion. The Feast obviously has an emotional and symbolic relevance in the narration of their lives, tying together religious symbols, cultural displays, places and people. The religious festival is portrayed as keeping together the neighbourhood and the migrants, those who came and those who went away, Italians, Irish, and Jewish... Contemporary images from YouTube counterpoint their proud description of its organisation and popular success: marching bands, joyful viva!, children smiling. The images intentionally bridge phatic breaks and syntactical inconsistences in the raw footage. The pauses and the lingering on allow for visual repetition, which delivers consistency both to their narration and to the feast itself. Little by little, the Feast transforms from a coral to a personal event, as details of family history are disclosed to the audience. It is at this point that sequences of vintage family memories posted on Facebook and You Tube begin to populate the narration, such as the following one. 
This media file cannot be displayed. Please refer to the online document http:// journals.openedition.org/anthrovision/2359

Link: https://www.youtube.com/watch?v=ydW5yJFVB_Y

15 The film is narrated by two prominent members of the St. Anthony's Society ${ }^{2}$, Jason and Paul. The two protagonists, as in a duet, refer to the same practice and neighbourhood. Yet, their stories do not always run parallel, but overlap and diverge according to their personal reconstruction of collective memory. The slight inconsistences are played up by montage-like juxtaposition with YouTube videos representing yet other viewpoints in and on the Feast. The protagonists themselves call into play the authority of distinguished guests, and in the same breath undermine such authority by telling humorous anecdotes about them. So it is with the coming of the Archbishop from Padua to bring the relic of the Saint, the visit of Pope John Paul II to Boston, and the performance of fascist marches in front of Bill Clinton. Grasseni (2014) comments on the uncanny experience of witnessing the procession band playing a fascist motive while petitioning the Saint. This footage is in the film, as well as the elicited reaction of the interviewee, who explains that this is one of the requested songs by one of the families that greet the statue of St. Anthony with votive offerings. He then proceeds to "tell a story" to Grasseni, to deflate the political significance of this nostalgic tune. Even "to the future president of the United States" did "they" play "fascist music", as this has by now become part of a nondescript folk repertoire: "oldtimers know", but "it was so long ago", and nowadays this tune has no political undertone for this community - claims Jason in the film (Christmas in August, minute 15). The irony they convey is represented through the montage-juxtaposition of ethnographic and social networks footage: contrasting the intimate and the public, the understated and the boasted. Beyond plain banter, the overall ironic effect is that of narrating by untold contradictions, which are nonetheless held together by affection.

Juxtaposition also highlights the important issue of changes and differences between the American and the Italian tradition of the Feast. The Feast in Italy is represented as pious and solemn. The soundscape of the procession includes only church bells and a megaphone-enhanced rosary recitation. Boston's Feast, on the other hand, is all but meditative. A sense of loud enjoyment characterises most on-line videos (as well as Grasseni's footage of two editions of the event). Looking back to a model Feast as recalled from childhood contextually opens up a space of self-determination, defining a different Feast practice and a different way of being Italian today in Boston. Being "a real Italian" emerges as an ironic counterpoint in both conversations. Paul's comment on the difference between "a real Italian, and someone who thinks they are Italian" hinges on the (self)perception of having an innate capacity for stylishness: "on their worst day, they'll look like they are going somewhere important - any they may be going nowhere!" (Christmas in August, minute 15). This notion is also echoed in the Facebook comments to a photo taken in the Thirties, recalling specifically the days in which the marching band "looked Italian" because they were so rigorously well-dressed 
Being Italian is a mixture of performance and paraphernalia, identification and rooting. Jason noticeably points out that "I don't know if it is a show we put on or a part of us that comes out" (Christmas in August: 19'). Anthropologist Augusto Ferraiuolo, who features in the film, responds that on the basis of his own ethnographic research, one identifies with Montefalcione with regard to St. Anthony's devotion, but with Italy altogether for example on occasion of a World Cup football match. The You Tube clip that De Musso chose to follow this remark shows a cheering young crowd in the North End during the Football World Cup, which Italy won in 2006. The clip blends Italian flags and the easily recognisable blue shirts of the national team over a drum and base surge that sounds more like Jersey Shore than St. Anthony's Feast. Such performance is (self)recorded, posted and shared. It feeds on habits as well as on active idealization of what an Italian is or should not be. Thus social networks carry out the function of technologies of identity, sustaining an imagined community in a similar way to what Benedict Anderson describes as the seminal work of the press and mass media in the diffusion and acceptance of national identities (Anderson 1983).

The abundant visual and musical materials circulating in social networks tell a different story than the Jersey-Shore or Soprano-like stereotypes of Italian Americans, while at the same time surprisingly confirm some forms of indulgent selfcategorization. We enter the sensitive grounds of what Michael Herzfeld has called "cultural Intimacy", namely "the recognition of those aspects of a cultural identity that are considered a source of external embarrassment but that nevertheless provide insiders with their assurance of common sociality" (Herzfeld, 2005: 3). Following Herzfeld, here active self-stereotyping amounts to a social poetics, a performance constantly challenging the borders between invention and convention, where selective forgetting and remembrance coexist, and collective narrations are woven to build future and make sense of the past. These are competing, contestable and constructed narratives. However, by entering the dimension of collective storytelling, they play an active part in apprenticing to and the social performance of self-stereotypes.

Gestures represent an important source for storytelling. They constitute an important part of cultural intimacy (Herzfeld 2009). Through the cultural competence of the body we access proper identity performances. In order to render such performative embodiment in the film, we coupled gestures in the footage with same gestures in You Tube clips. For example, Jason mimics the blessing gesture of the Pope and of the Archbishop during his interview. These gestures are visual shorthand with which the interviewee, actually an accomplished storyteller, evokes images to the mind of the viewer in order to better recreate the atmosphere of the events. Finding these events independently posted in the cloud - and editing them into the 'talking head' interview with Jason - allowed us to couple his gesture with the actual archival footage, almost to visualize his intimate recollection of the very gesture that the Archbishop performed. Being captured on camera, the Archbishop's blessing was then posted on the web, and Jason mimicked it in front of our camera to picture the intimacy of his memories. This 
makes an important counterpoint to the widespread conviction that ethnographic filmmaking should be a naturalist mimicry of unfolding activities. These activities themselves mimic deeply layered recollections and models of action, an increasing portion of which comes already 'mediated' by the circulation of images on social media.

The rhythm of montage follows the beats of drums and brass bands accompanying the Saint's procession, switching from talking heads to the Feast footage, to the archival material. The band's procession leads and connects a cartography of soundscapes. As Grasseni (2014) notes, the marching bands' itinerary acknowledges and confirms the liminal boundaries of the community, petitioning the saint with certain specific songs that each of the families living (or once living) on that specific street corner (used to) like. As long as one neighbour is left down a narrow alley, wishing to pin a dollar bill on the Saint, the march will pursue that door (Christmas in August, 21'). The North-End relives at the sound of "Number One". The Marcia Reale sanctions that the dollar bills are being pinned on the saint. The marching bands and the motives they play to petition for the saint are the main soundtracks of the photo-souvenirs posted on the web (Monte Boston13, 2013; Tsmeriglio 2013). Local film-makers reconstruct the history of the North End based on this unprecedented reservoir of part home-movies, part digital oral history (North End Water Front 2012)3. Together, these productions congeal into a collective stereophonic, cinematic memory and play an important role in the dialectic between tradition and innovation.

In the final weekend of August, in Boston's North End, a broad musical repertoire resounds. "Feast music" (an expression that Jason uses in Christmas in August) includes romantic folk Italian songs but also the Italian rendition of the Brazilian motif "A Banda" (Mina/ Chico Buarque de Hollanda /Antonio Amurri 1967). This is the music score of a YouTube edit of 1960s, super8 sources (MonteBoston13 2008). To adopt this song in Christmas in August meant to evoke the association with Italian pop culture but also to document the unusually wide musical repertoire that embodies devotional tradition. "Feast music" charts a comprehensive taxonomy of affection - ranging from the fascist songs that "they played even to the future president of the United States" to 1960s international pop. Tradition is thus not fixated in a national repertoire, it is liminal and dynamic, just as the Feast itself: it encompasses both Sirtaki and "Never on Sunday". Eventually, contemporary drum and base might well become a cultural reference, side by side with the catchy melodies of "Feast's music".

This holds true for images as well. On the St. Anthony's Feast Facebook page, tailormade suits and flower-carts coexist with sunglasses and t-shirts in the same way super8 footage accompanies high-definition, wide-angle deformations. The Feast is an audiovisual sediment of urban material culture as it evolved in the North End, stacked in many layers on YouTube. Italian-ness is nowhere to be pin-pointed, but everywhere to be seen and heard. A core repertoire of domestic scenes, sacred icons, and food incorporated heterogeneous new traits over time, including clothes and hair-does. People's appearance is shaped both by bodily features and video formats. The images shake and pan, distorting more than once. Formats can be boxed or stretched. Actual film grain and post-production filters (typically sepia colour correction or film-stock effects) visually gloss together nostalgia and the contemporary Feast.

Central to the Feast is its relation to the Saint. This relation of devotion is differently but clearly articulated by the two interviewees to the sceptical anthropologist (De Musso and Grasseni: 8'): they insist that it is Saint Anthony the main attraction. People 
come to the North End to see the saint: "After they see St. Anthony they do what they feel... whatever is in their heart. Then they'll eat something, they listen to some music and then they see St. Anthony again. The rule is St. Anthony" says Paul. The Saint is carried in good sight throughout the neighbourhood, embedding the Italian-American sociality into actual streets, yards and balconies, emotionally drawing together the devotees. The Archbishop captured on vintage footage also underlines the visual activity on and around the saint, when he urges the crowd to "look how beautiful he is! Look at St. Anthony!"” (De Musso and Grasseni:13'). In fact, icons of the saint can be found everywhere. They embellish houses, restaurants and the hats of the marching bands' members. Badges of St. Anthony and of St. Lucy are offered to the devotees who pin their dollar bills. The badges mark the bearing of a very local identity and testify to the offer made. Once the red bricks are left behind though, beyond Hanover street, they become embarrassingly exotic, perhaps passé.

Devotional badges, Festival of St. Cosmas and Damian

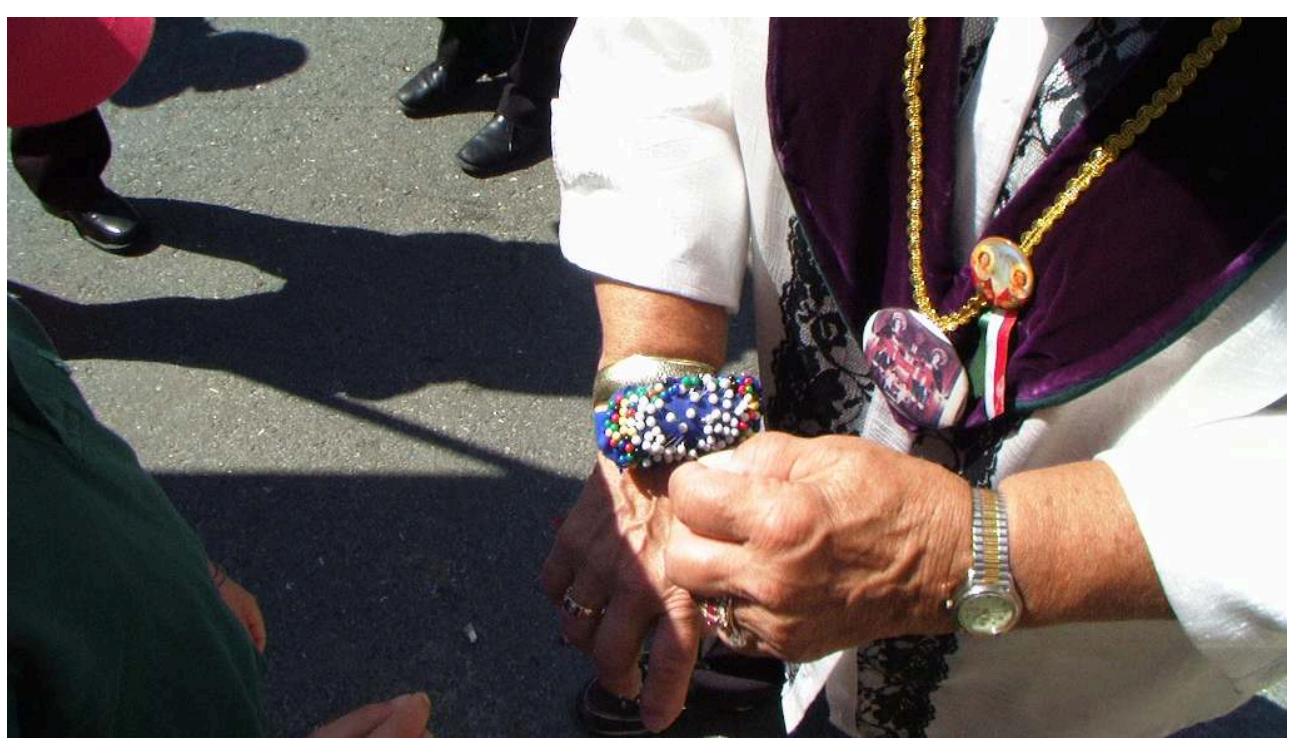

Figure 3, East Cambridge September 2011. Festival of St. Cosmas and Damian.

Photo by Cristina Grasseni

In these moments of heightened collective performance, lineages and attachment to one's village of origin are eagerly self-ascribed - and attempts are made at speaking a language or dialect mostly forgotten or unknown to the new generations. Iconic images or pictures taken at the procession inhabit the Facebook page. The success of the feast is symbolised by the statue of the saint, fully covered in dollars, following a traditional devotional practice of offerings to the saint that is documented well beyond the Italian South (Ferraiuolo 2009; Zanotelli 2006). Not only dollars, but prayers, names and images of deceased people are attached to the saint. Families double pin their memory to the saint and posting images to the online board. However, the relation with the saint goes beyond contemplation and symbolization. The corporeal performance of devotion is something as intimate as a bodily practice. The saint is a close and familial figure. One kisses the relics, one kisses the statue. One raises one's child to kiss the statue. For the male members of St. Anthony society, "he is one of the guys" - but not just for those who organise the Feast. He is touched, grabbed and kissed by anyone in the neighbourhood. They wait for him on their balconies; they line up and follow him 
in the procession. This physical attachment to the Saint strongly connects the Feast with catholic traditions of devotion that are to be found in Italy and beyond (Bonato 2005, Ballacchino 2009, Bindi 2009). It entails a highly somatic participation - both of the attendees and of the saint. This dimension is well depicted by the amateur cameras aimed, like everybody's attention, at the devotional money-pinning. The movement of the camera "sets the rhythm of images and sounds and delineate a trajectory" (Manoukian 2009: 249), which we can follow to find the focal point of the Feast: the statue of the saint

The Feast warps the urban landscape of the North End around the Saint's statue. Confetti, ribbons, and red brocade welcome the resting statue... together with stages, food stands and souvenir vendors, the statues' stand is a paramount feature of the festive sensorial landscape. These ephemeral markers blend in with more permanent elements such as restaurants, signs, bakeries, bars, and banners that remind one that the North End is an Italian neighbourhood - for tourist reasons and all-year-round. The local shops are among the sponsors of the Feast. At the time of filming, the president of St. Anthony of Padua from Montefalcione Inc. was the owner of a popular restaurant located just next to the society's headquarters; footage of one of the most lively celebrations take place in a famous pizzeria where, among the viva!, alongside the name of St. Anthony and St. Lucy ${ }^{5}$ we hear the name of the restaurant over the clash of cymbals (De Musso and Grasseni: 20'). Italian-ness and St. Anthony are local resources and important symbolic assets for the success of North End entrepreneurs who, together with the other commercial sponsors (mainly food-related and with important associations with Italian-American heritage), shape the feast by metaphorically pinning their sponsorship.

The identification of the neighbourhood and the community around the feast follows a centripetal dynamic by which diversities and alterities are composed by pledging interest and participation. Different origins and generations connect to the core and thus claim belonging: as the people of Montefalcione "were getting less and less" (De Musso and Grasseni 2013: 3'), the Feast incorporated people from different Italian regions, which in the North End translated in different street corners ${ }^{6}$, eventually incorporating some Irishmen and the "good Jewish guy" who are now part of the St. Anthony society. We propose the notion of the stew in alternative to the melting $\operatorname{pot}^{7}$ to describe the continuing relation of the Feast to the Italian diaspora, while evidently moving on from being a "Monti" affair to representing the North End, to Boston itself. The Feast won the Best Festival of Boston award in 2014, in an urban context that encourages rather than dwarfing cultural events predicated on heritage or ethnic affiliation, also for evident commercial reasons.

\section{Virtual Intimacy}

With limited connections remaining to the native village in Italy, Boston's many Societies of the Saints recurrently and symbolically organize sizeable displays of ethnicity in the form of theatrical devotion (Ferraiuolo 2009). The festival of St. Anthony, involving thousands of people, catalyzes shared memories that have already developed over generations as part of a fully American kaleidoscope. The procession with the Saint and the band reproduces the relationship between collective (self)narration, stereotypical performance of Italian-ness, and religious devotion as an 
urban practice of place-making. There are also other occasions during which St. Anthony's society makes its voice heard, for example to post commemorative comments on specific religious festivities such as Easter, to publicize the society's accomplishments, to disseminate news about cultural activities about the North End, or to acknowledge support from prominent politicians (such as the current Boston Mayor who participated in the 2014 Feast).

The Boston Marathon Bombing of 15 April 2013 was an ominously unique occasion on which the Facebook group posted, firstly a brief informative message about the citywide lockdown ${ }^{8}$ and, a few days after, a call to a candle-light vigil in the North End in collaboration with the other "societies of the saints". Grasseni attended the vigil of Sunday 21 April 2013, a somber and dignified procession concluded by brief ceremonial speeches and a candle-laying ceremony at the Prado, under the statue of Paul Revere a landmark in the North End and in the history of the American Independence. The event was well documented, ${ }^{9}$ with 46 named group members participating (as recorded on Facebook) and perhaps a few more physically attending in person - no more than one hundred perhaps. Overall, considering that the two million inhabitants were stirring after a truly shocking lockdown and that vigils and "Boston Strong" T-shirts were emotionally multiplying in the streets and on-line, the scarce attendance could only be telling of the dwindling numbers of actual Boston residents who could, at a day's notice, mobilize and come in attendance.

Beyond the actual physical gathering in the streets, though, the increasingly popular Facebook page (currently "liked" by 6109 people) ${ }^{10}$ and the exchange of vintage footage, songs and carefully edited tributes online contribute to the all-year-round selfportraiture as a community, when hardly any residential rooting is left in this now gentrified neighbourhood. This 'virtual' community is in fact, following Miller a 'real' community. Although these relations exist thanks to digital and remote modes of interaction, they are invested with importance (2000: 7; 67-68). They also are sometimes preferred to attending the physical procession - as proven by the scarce attendance of the vigil. They signify participation to the procession in a place that is other than the one of one's physical abode, but not detached from it. We thus maintain the expression 'virtual intimacy' here, rather than 'digital intimacy' for example, because we do not simply wish to comment on how the digital dimension enables and is conducive to cultural intimacy in characteristic ways. We want to stress the elective character The virtual intimacy of the Facebook page also feeds off the physical attendance and the pervasive camera presence at the actual Feast, in a recursive loop of mimicry and recollection as indicated above.

By looking at the St. Anthony's Feast Facebook community, we are confronted with a diverse corpus of materials - mostly videos and photographs of the latest Feast or event. A large number of members use them as "videos of affinity" as defined above, especially in relation to the Italian diaspora and the notion of Italian-ness. This is in fact a notion that we debate in the film, when Paul offers a complex and colourful palette of personal experience, family remembrances, and stereotypical expectations about what "a real Italian" should look like.

This media file cannot be displayed. Please refer to the online document http:// journals.openedition.org/anthrovision/2359 

sure, but also than the online users (a claimed 300,000-strong street presence). The community that is thus symbolized online comes together as a practice or performance, regardless of whether everyone participates in it. Across multiple social networks, photos, videos and comments create a meta-network that complicates the ecology of belonging around the Feast. As pointed out by Martin Wahlberg in his work about virtual memorials, videos and comments aim to tell a story, evoking a private narration in which the opinions and values of the community are embedded (Wahlberg 2009). By participating ethnographically in the practice of the Feast, and by incorporating in the film the videos of affinity and of affiliation that precede, accompany and follow its three-day long performance, we intended to represent both the practice (the Feast in the flesh) and the community itself, whose intimacy is both real and virtual, and certainly digitally mediated.

Being present - however vicariously - is fundamental. Access to these pictures allows participating in the many activities that would be impossible to attend in person. This is of course not only true of festive events. Analysing video of political demonstrations in Iran, Setrag Manoukian underlines the importance of YouTube videos for connecting political activists engaged in demonstrations and their diaspora spectators (Manoukian 2009). The event is both documented (thus rendered real) and made relevant (through the experience of closeness) by watching the video. Although evidence is not at stake here, participation and proximity are a highly valued component of the Feast. In the online community just as much as in a real one, not everybody has the same visibility and prominence. One's record of online participation and one's actual involvement in the Feast shape one's position and charisma. For example, participating in the Feast and then posting and commenting back constitute a fuller, on-line meta-experience that integrates the actual attendance of the event. This holds true especially for those 
networks that meet both on and offline (as in the case of the alternative food networks investigated by Grasseni 2013 and De Musso 2013). Besides the authority established by regularly posting and commenting, however, peripheral characters may also smuggle peripheral materials and ideas into the conversation. These too become part of the "metadata" of the entire community: a common pool of imaginary resources. This veritable corpus of representation follows and augments the Feast over the years. It is this corpus, together with the community of practice, that constitutes the field-site for our documentary work.

The identity of the Feast is heavily dependent on the notion of an Italian American neighbourhood party, thrown out of religious devotion in honor of the local patron saint. St. Anthony's Feast mimics and appropriates the original devotion of St. Anthony of Padua in Montefalcione, Italy. Its import to Boston - together with that of several others patron saints and "societies of the saints" - helped shaping the identity of the North End and of several other neighbourhoods, often reproducing and mapping the initial geographical provenance of many Italian migrant communities, including their internal differentiations and competitions (Ferraiuolo 2009). Changes are constantly referred to by the two interviewees in the film: not only the evolution of the feast itself, but also the transformations in the social composition of the neighbourhood. As Jason, the procession leader, explains: "The family is not at the building anymore. But I play that song. Cause it's always been played here. So it's something in my head - oh, we have to play that song" (De Musso and Grasseni 2013: 26'). Thus a process of ongoing belonging - ideally reaching beyond the boundaries of life itself - links close and far away people, especially those who used to go to the Feast in their childhood. Videos compensate the relative lack of participation with online relationships and mutual support - and such power of intimacy is maintained even when the Feast is actually extremely well-attended: St. Anthony's attracts up to 300,000 people according to its organizers. However, the online presence of the "society of the saint" is just as important. It compounds the Feast's performance with the collective remembrance of a community that is as much virtual as it is "real" (as explored by Boellstorff 2008 in the case of Second Life users).

On YouTube and Facebook, photos and videos allow people to get together trying to identify people in the images, connecting faces to (possibly departed) relatives, and guessing who could have possibly have taken the pictures.

This media file cannot be displayed. Please refer to the online document http:// journals.openedition.org/anthrovision/2359

Link: https://www.facebook.com/StAnthonysFeast/photos/pb. 208237425878346.-2207520000.1416341392./412357708799649/?type=3\&theater (accessed February 6, 2017)

This media file cannot be displayed. Please refer to the online document http:// journals.openedition.org/anthrovision/2359

Link: https://www.facebook.com/StAnthonysFeast/photos/pb. 208237425878346.-2207520000.1416341392./412357742132979/?type=3\&theater (accessed February 6, 2017) 
This media file cannot be displayed. Please refer to the online document http:// journals.openedition.org/anthrovision/2359

Link: https://www.facebook.com/StAnthonysFeast/photos/pb. 208237425878346.-2207520000.1416341392./416457081723045/?type=3\&theater (accessed February 6, 2017)

The socialization of photographs on Facebook is part of a collective effort to trace back relations while it consolidates interest around the Feast. In this way, it works as an interactive archive. Pelle Snickars discusses how Web 2.0 gave birth to a new social understanding of archival practices (Snickars 2009). Access to social networks has changed the way in which people approach photographic archives, and thus the way in which they conceptualize archives altogether. Archives are no longer buildings with limited access to collections, explored by lonely researchers (Prelinger 2009). Rather, they are now epitomised by companies such as Google and Yahoo, which consolidate (corporate-controlled) access to "the world's largest repository collection for digital photos and videos" (Bianco 2009: 307). Despite blatant issues of corporate control of collective and private memories as well as of use (and privacy) of public and private data, their socialization implies that images on Facebook and YouTube function as the private-public archive of the community, easily accessible and constantly open to updates. The images are shared and hence saved, both in the cloud and in the actual recollections of the Facebook Group members. They re-create sense of belonging through a practice of mediated remembrance. Thus the changes in the neighbourhood, namely the gentrification and dispersal of the original migrant community that is one of the recurrent motives in the documentary interviews, are acknowledged and accommodated in personal narratives. The Feast provides a reliable "common place" in which people's lives and identities become objects of recollection and reverie.

\section{Conclusion}

We have dwelt on the dialectic and dynamic nature of the sources juxtaposed in Christmas in August, which we obtained by literally mining a collective imaginary: combining ethnographic and found footage, from digital archives and social networks. Montage is the formal principle through which non linearity is allowed back into the narrative, allowing for the contamination of different voices, viewpoints and temporalities. Our ambition was to achieve both an overview (the Übersichtlichkeit of Wittgenstein's family resemblance) and an ironic distance from the dominating narrative of observation.

Michaela Schäuble's workshop, convened in 2013 at the Mahindra Center for the Humanities of Harvard University, prompted us to "mine imagination" beyond and "outside an essentially realist and mimetic paradigm" of ethnographic approaches to visual production. ${ }^{12}$ "Medial manipulation" was one of the expressions used in the call, and we find it an apt term to characterize the making of this film. "Manipulation" also expresses our own initial disquiet and ambivalence about using footage from social networks, consequently finding ourselves tracking and charting, emboldened by the task of matching nicknames on YouTube with other Facebook nicknames, and tracing them to personal identities through the society or associated web sites. While the 
different degree of graininess of the clips plundered from You Tube functions as a device for pictorial quotation, their juxtaposition with own ethnographic footage and talking-heads poses new interrogations. The result is hopefully a dynamic assemblage of personal and collective imaginaries, illuminating their cohesive and conflicting nature while contributing to the emergence of a collective self-representation.

Being Italian, being a North Ender, being American and Bostonian are selfidentification practices that overlap in the performance of the Feast - all of which are present in the self-representations that Feast-goers craft and collect on the web. Corporeal and virtual, visible and invisible, soundscape and landscape concur in they ways of inhabiting the Feast. The latter gathers thousands of people, few of whom regularly access the online group. Nonetheless, both physical and virtual participants imagine and perform a community. Belonging is pinned at multiple levels - we hope to have shed some light on this complexity, as well as on potential interaction between media archaeology and ethnographic filmmaking.

\section{BIBLIOGRAPHY}

\section{Books and articles}

Anderson, B. 1983. Imagined Communities. Reflections on the Origin and Spread of Nationalism. London: Verso.

Ballacchino, K. 2009. (ed.) La Festa. Dinamiche Socio-Culturali e Patrimonio Immateriale. Nola: L'arcael'arco Edizioni.

Bianco, J. S. 2009. Social Networking and Cloud Computing: Precarious Affordances for the "Prosumer." Women's Studies Quarterly, 37 (1-2) pag. 303-312.

Bindi, L. 2009. Volatili Misteri. Festa e Città a Campobasso e Altre Divagazioni Immateriali. Roma: Armando Editore.

Boellstorff, T. 2008. Coming of Age in Second Life. An Anthropologist Explores the Virtually Human. Princeton University Press.

Bonato, L. 2005 (ed.) Festa Viva. Continuità Mutamento Innovazione. Torino: Omega Edizioni.

De Musso, F. 2013. Orange Landings. Networks and relations. MA Thesis, University of Bologna.

Ferraiuolo, A. 2009. Religious festive practices in Boston's North End: Ephemeral identities in an Italian American community. Albany: State University of New York Press.

Grasseni, C. 2013. Beyond Alternative Food Networks. Italy's Solidarity Purchase Groups. London: Bloomsbury.

Grasseni, C. .2014. "The Atlas and the Film", AnthroVision [Online], 2.2 | 2014, Online since 29

December 2014, connection on 30 December 2014. URL http://anthrovision.revues.org/1355.

Grimshaw, A.,

Ravetz, A., 2009. "Rethinking Observational Cinema", Journal of the Royal Anthropological

Institute, 15(3): 538-556. 
Herzfeld, M. 2005. Cultural Intimacy. Social Poetics in the Nation-State. New York: Routledge.

Herzfeld, M. 2009. "The cultural politics of gesture. Reflections on the embodiment of ethnographic practice", Ethnography 10(2):131-152.

Herzfeld, M. 2012. "Radici antiche, razzismi recenti: passato, stirpe e lignaggio negli stati nazionali dell'Europa meridionale", in A. Cnnas, T. Cossu and M. Giuman (eds.) XENOI. Immagine e parola tra razzismi antichi e moderni. Napoli: Liguori, pp. 253-266.

Lange P.G. 2009. "Videos of Affinity on YouTube." In Snickars, P and P. Vonderau (eds.) The YouTube Reader. Stockholm: National Library of Sweden, pp. 70-88.

Lave, J. 2011. Apprenticeship in critical ethnographic practice. Chicago: University of Chicago Press.

Manoukian, S. 2010. "Where Is This Place? Crowds, Audio-vision, and Poetry in Postelection Iran.” Public Culture 22 (2): 237-263.

Marcus, G.E., 1994. “The modernist sensibility in recent ethnographic writing and the cinematic metaphor of montage" in: L. Taylor (ed.) Visualising Theory. London: Routledge, pp. 37-53.

Miller, Daniel, and Don Slater. 2000. The Internet: an ethnographic approach. Oxford: Berg.

Niezen, R. 2013. "Internet Suicide: Communities of Affirmation and the Lethality of Communication”. Transcultural Psychiatry 50 (2): 303-22. doi:10.1177/1363461512473733.

Posen, S.I., and Sciorra, J. 1999. “'We go where the Italians live'. Religious processions as ethnic and territorial markers in a multi-ethnic Brooklyn neighborhood”, in Orsi, R., (ed.), Gods of the city: religion and the American urban landscape, Bloomington: Indiana University Press.

Prelinger, R. 2009. “The Appearance of Archives”. In Snickars, P and P. Vonderau (eds.) The YouTube Reader. Stockholm: National Library of Sweden, pp. 268-274.

Sciorra, J. 1985. "Religious Processions in Italian Williamsburg", in The Drama Review, Volume 29, No. 3, Massachusetts Institute of Technology.

Snickars, P. 2009. “The Archival Cloud.” In Snickars, P and P. Vonderau (eds.) The YouTube Reader. Stockholm: National Library of Sweden, pp. 292-313.

Turkle, S. 2012. Alone Together: Why We Expect More from Technology and Less from Each Other. New York: Basic Books.

Wahlberg, M. 2009. "YouTube Commemoration: Private Grief and Communal Consolation". In Snickars, P and P. Vonderau (eds.) The YouTube Reader. Stockholm: National Library of Sweden, pp. 218-235.

Zanotelli, F. "Denaro in Festa. Note su economia e identità nel Messico 'meticcio'", in L. Bonato (ed.) Festa. Tradizione Territorio Turismo, Torino: Omega Edizioni, pp. 275-283.

Films

Albence, A. 2012 St. Anthony's Italian Festival-Feast Day Procession 1977. Yotube, https:// www.youtube.com/watch?v=ydW5yJFVB_Y (accessed January 6, 2015)

Ballacchino, K. 2007 La Festa Migrante. I Gigli di Nola a New York. Video, 14'.

De Musso, Federico and Grasseni, Cristina 2013. Christmas in August. Boston's St. Anthony's Feast. Video, 30 mins https://vimeo.com/63213733 (accessed February 6, 2017)

Grasseni, C. and F. De Musso 2013 Christmas in August. Boston's St. Anthony's Feast. Video 30'

MonteBoston13 (uploaded by) 2008 St. Anthony's Feast North End, Boston 1973.Youtube. https:// www.youtube.com/watch?v=HcqxhMx3uG0 (accessed January 6, 2015) 
Mina, "La banda" 1967 by Antonio Amurri. Translation of "A banda" by Chico Buarque de Hollanda 1966.

MonteBoston13 (uploaded by) 2013 PATRON SAINT: The Montefalcione devotion to Saint Anthony. Youtube. https://www.youtube.com/watch?v=xhiaVhdy3jY (accessed January 6, 2015)

North End Water Front (uploaded by) 2012 Film Preview - Boston's North End: America's Italian Neighborhood. Youtube.

https://www.youtube.com/watch?v=C4w8FgqnHPA (accessed January 6, 2015 )

Tsmeriglio (uploaded by) 2013 New 1996 Boston St Anthony Feast. Youtube. https://

www.youtube.com/watch?v=NfC-FvWGyzo (accessed January 6, 2015)

Webistes

De Musso, Federico and Grasseni, Cristina 2013. Christmas in August. Boston's St. Anthony's Feast. http://christmasinaugust.altervista.org/ (accessed February 6, 2017)

St. Anthony's Feast Facebook Group (https://www.facebook.com/StAnthonysFeast) (accessed February 6, 2017)

\section{NOTES}

1. A special thanks goes to the Film Study Center at Harvard University, Harvard Sensory Ethnography Lab, and the Radcliffe Institute for Advanced Study at Harvard University, which made this project possible with a joint fellowship as David and Roberta Logie and Radcliffe-Harvard Film Study Center fellow, 2011/2012.

2. We refer here to San Antonio Di Padova Da Montefalcione, Inc.

3. For a comparative case, see Ballacchino 2007. In this film, the author sourced 1960s footage of returning migrant families illustrating how the Gigli feast migrated from Nola to Williamsburg, NY. In our case, we first "found" the footage on line and then traced it back to known authors. In the case of Ballacchino, the footage was not in the public domain and was entrusted to her by the informants. However, our contribution is only one of the many voices within an already crowded public space of (self)representation.

4. In Italian in the video: "Vedete com'è bello! Guardate Sant'Antonio!”

5. In Italian in the video: Sant'Antonio and Santa Lucia.

6. See North End Water Front 2012.

7. As in the salad bowl, in the stew each ingredient is identifiable, but they slowly become more permeable and finally season each other.

8. "We hope that all of our family and friends are safe this afternoon. Please evacuate the Copley Square area if you are nearby and can leave. Many buildings are in lockdown mode as a result of the explosion near the finish line of the Boston Marathon. Our thoughts and prayers are with those that have been affected by this senseless tragedy" posted 15 April 2013 at 15.40. The message was followed by a Keep Running, Boston sympathy flier to share and reuse, on 15 April 2013 at 17.27. They day after a further post with a link to a 2008 video on You Tube: the Defenders Alumni Corps performing America and Maybe at The Old North Church as part of the 2008 St. Anthony's Feast. The 
post reminded the community that "The members of Saint Anthony and Saint Lucy Societies are proud Americans and proud Bostonians."

9. See the event description and photographs on https://www.facebook.com/media/ set/?set=a.10151339489566179.1073741833.117093491178\&type=1 (accessed February 6, 2017)

10. On 24 May 2016, St. Anthony's Feast records 6,109 'likes'. On 2 January 2014, it recorded 4,235. In September 2011, when the group was 'closed', Grasseni was group subscriber number 2,003.

11. For a different approach to online community building, see Niezen 2013. Niezen's definition of online 'communities of affirmation' also stresses the enabling function of the digital medium, but for identities that exist online because they would be perceived as pathological in face-to-face interactions.

12. Mining Imagination. Ethnographic Approaches Beyond Knowledge Production, Volkswagen Fellows Symposium convened by Michaela Schäuble, Mahindra Center for the Humanities, Harvard University, April 5-6 2013.

\section{ABSTRACTS}

Taking as a point of departure the Italian American community in Boston and its process of collective remembrance surrounding Saint Anthony's Feast, we addressing the limits and potential of montage. We argue that the multi-vocality and multi-temporality of social networks can be incorporated into the linearity of a narrated film. We discuss how editing found footage into the film Christmas in August (2013, http://christmasinaugust.altervista.org/) was a way to explore the assemblages of diasporic identity and cultural intimacy for Boston's Italian Americans. We focus specifically on the significance of social networks as mediators, and of montage as a tool to capture the virtual narratives and identities performed in the Facebook Group Page of St. Anthony's Feast. We look at the Internet as both an archive source and a field of performance for acts of commemoration and remembering, and argue that montage is the most suited editing technique to reproduce the intimacy and irony expressed by the protagonists in their performance of Italian-ness.

Prenant comme point de départ la communauté italo-américaine à Boston et les techniques de mémoire collective déployées autour de la fête de Saint Antoine, nous abordons les limites et les potentiels des techniques de montage. Nous prétendons que la multi-vocalité et la multitemporalité des réseaux sociaux peuvent être inclus dans la linéarité d'un film. Nous discutons de la manière dont le montage de film récupéré/ détourné comme dans le film Noël, au mois d'Aout (2013 http://christmasinaugust.altervista.org/) est une façon d'explorer les modalités de recomposition d'une identité diasporique et d'une intimité culturelle pour les italo-américains de Boston.

Nous nous concentrons plus spécifiquement sur l'importance des réseaux sociaux comme de possibles médiateurs et du montage comme d'un outil pour capturer les récits et identités virtuels mises en scène sur la page Facebook des fêtes de Saint Antoine. Nous avons considéré internet comme sources d'archives et un terrain de performance propice aux inscriptions de 
souvenirs et de mémoires. Nous démontrons que le montage est la technique la plus adaptée pour rendre compte de l'intimité et de l'ironie exprimées par les protagonistes pour exprimer leur "italianité".

Tomando como punto de partida a la comunidad italiana americana en Boston y su proceso de recuerdo colectivo alrededor de la Fiesta de San Antonio, abordamos los límites y potencialidades del montaje. Argumentamos que la multi-vocalidad y la multi-temporalidad de las redes sociales pueden ser incorporadas en la linealidad de una película narrativa. Discutimos cómo la edición de archivos encontrados para la película La Navidad de agosto (2013, http:// christmasinaugust.altervista.org/) fue una manera, para los italianos de Boston, de explorar las recomposiciones de la identidad diaspórica y de la intimidad cultural. Nos centramos específicamente en la importancia de las redes sociales como mediadores y del montaje como una herramienta para capturar las narrativas e identidades virtuales representadas en la página del grupo de Facebook de la Fiesta de San Antonio. Consideramos Internet a la vez como fuente de archivo y como campo de actuación para los actos de conmemoración y recuedo, y argumentamos que el montaje es la técnica de edición más adecuada para reproducir la intimidad y la ironía expresadas por los protagonistas en su representación de la "italianidad".

\section{INDEX}

Palabras claves: religión, diáspora, Facebook, paisaje sonoro, edición fílmica, montaje

Keywords: religion, diaspora, Facebook, soundscape, film editing, montage

Mots-clés: religion, diaspora, Facebook, espace sonore, montage filmique, montage

\section{AUTHORS}

\section{CRISTINA GRASSENI}

Leiden University

Cristina Grasseni is Professor of Anthropology at Leiden University (the Netherlands). Following her seminal work on Skilled Visions (Berghahn 2007), her research interests include visual and sensory ethnography and the processes of mediation of ethnographic knowledge.

C.Grasseni@fsw.leidenuniv.nl

Together, De Musso and Grasseni have co-authored the film Christmas in August (http://

christmasinaugust.altervista.org/, 2013). 